\title{
Sacredness of Dayak Ribun Forest: Knowledge, Livelihood and Belief
}

\author{
Arkanudin ${ }^{1, *}$, Mashudi $^{2}$, E. Sutandar ${ }^{3}$ \\ ${ }^{1}$ Faculty of Social and Political Sciences, Tanjungpura University, West Kalimantan, \\ Indonesia \\ ${ }^{2}$ Faculty of Teacher Training and Education, Tanjungpura University, West Kalimantan, \\ Indonesia \\ ${ }^{3}$ Faculty of Civil Engineering, Tanjungpura University, West Kalimantan, Indonesia \\ *Corresponding author: Erwin_sutandar@yahoo.com
}

\begin{abstract}
This study aims to describe the knowledge system of the Ribun Dayak tribe about their forest in West Kalimantan. The knowledge system of the Dayak Ribun community consists of knowledge of the community, knowledge of sources of livelihood, and knowledge of belief/religion. The research subjects were the Dayak Ribun tribe in Parindu District, Sanggau Regency, West Kalimantan. The approach used in this research is an ethnographic approach. Data collection uses direct observation techniques, in- depth interviews, and documentation studies. Based on the results of this study, it can be explained that the Ribun Dayak tribe has a unique knowledge system; First, knowledge of farming based on natural phenomena. Second, knowledge in the livelihood/livelihood system through shifting cultivation. Third, knowledge of belief systems and religion, even though they have embraced Catholicism and Protestantism,
\end{abstract}


but they have not abandoned the belief system of traditions, customs, and customary law which still functions as social control.

Keywords: Knowledge System, Dayak Ribun, Ethnography

\section{Introduction}

The Dayak sub-tribe in Parindu District, Sanggau Regency is the Ribun Dayak Ethnic. This ethnic group is a sub-ethnic of the Klemantan Dayak, which is spread in Parindu District and a small part of Tayan Hulu, Bonti and Kembayan. Currently, the number of ethnic Dayak Ribun is approximately 26000 people spread over 112 villages in the five sub-districts (Arkanudin et al, 2007). The distribution of the Dayak people in the interior of Kalimantan cannot be calculated by the number of sub-tribes in it (see Istiyani, 2008; White, 2009; Darmadi, 2016).

Asfar (2004) states that the distribution of the Ribun Dayak ethnicity in the four sub-districts is in 91 villages or villages. This ethnic group always calls themselves "Hibun" but "Ribun" this is because this ethnic group in its conversational dialect generally replaces the consonant sound (r) into a consonant $(\mathrm{h})$ both at the beginning, middle, and end of the sentence (Asfar, 2017).

Based on the results of research conducted by Arkanudin (2011) states that in Parindu District, these ethnic groups are spread in the villages of Central Damai, Sedoya, Bansu, Serosat, Kerosik, Luti, Tantang B, Sumpo, Topis, Pejugan, Layau, Mudun, Seranggas, Sungai Raya, Senara, Kerompang, Empiring, Lintang, Sembawang Bacong, Mawang, Musan, Engkalit, Sengoret, Tikas Melato, Engkala, Melabo, Modah, Amang, Empawek, Beruak, Brunai, Rakau, Keranjik, Doak, Suka Gerundi, Baharu, Tatang S and Engkayuk Village. The Dayak Ribun Indigenous People know the pattern of control over land and forests from generation to generation and continues to be practiced in community life. Control over customary areas is recognized and respected by the community, even verbally between communities knowing about the status and boundaries of land and forests that exist in the community (Mona, 2003).

Just like other ethnic Dayaks in West Kalimantan, the Dayak Ribun also have a variety of cultures and they still uphold the customs and culture that are their ancestral heritage. For 
example, although in their daily life elements of foreign culture have entered this ethnic life, namely with the presence of information technology objects and so on, they still uphold the teachings and customs of their ancestors (see also Mulyoutami, 2009; Prameswari, 2019; Niko, 2020). Along with the times, the Dayak Ribun forests are currently surrounded by oil palm plantations, so the threat in the future is that they may lose their cultural roots (see Sunker \& Santoso, 2019).

The local knowledge system of the Dayak community in Kalimantan is important to describe because of its sustainability, which supports the social life of the community (cf. Crevello, 2003; Mulyoutami et al, 2009). Therefore, this study answers the question, how do the Dayak Ribun people describe the sacredness of their forest existence?

\section{Method}

This research was conducted in Parindu Sanggau District, West Kalimantan. Selection of the area is as a test site with the consideration that the population of the Dayak ethnic group in the district Ribun is quite large and spread out in some village in the area of this district. For the purposes of data collection, the determination of research informants was carried out using purposive sampling technique.

The method used in this study is a descriptive method with an ethnographic approach. This research is to explore the ethnographic data of the Dayak Ribun ethnic group. Quoting Koeswinarno's (2015) article which states that ethnography is a writing about a particular ethnicity, which is usually written by an anthropologist. Ethnography is a direct observation activity that must be carried out through a natural approach, so researchers must adopt a behavior that respects or respects the social environment to obtain comprehensive ethnographic data (Kim 1993). Thus, the main focus of ethnography is the work to describe culture, and to understand other ways of life, and the way of life of other people (Spradley, 1980).

The data needed in this study include the main data collected centered on aspects related to the ethnographic framework. Data collection techniques were carried out by: (1) Participant observation (participant-observation), we went to the field and lived with the Dayak Ribun community; (2) In -depth interviews and casual conversations. 
In this study, researchers were provided with interview guidelines in the form of a list of questions, which would then be further developed in the field. Our interviews were conducted not only formally, but also informally by talking during breaks from working in the fields. As a tool in conducting the interview, the researcher used a voice recorder (tape recorder).

Currently the Dayak Ribun tribes, in the Parindu sub-district, are spread out in the village of Central Damai, Sedoya, Bansu, Serosat, Kerosik, Luti, Challenge B, Sumpo, Topis, Kuala Muri, Pejugan, Layau, Mudun, Seranggas, Sungai Raya, Senara, Kerompang. , Empering, Lintang, Sembawang Bacong, Mawang, Musan, Engkalit, Sengoret, Tikas Melato, Engjika, Melabo, Modah, Amang, Empawek, Beruak, Brunai, Rakau, Keranjik, Doak, Suka Gerundi and Baharu, Tatang S, Engkayuk Village. Thus, the informants in this study were tribal heads in each village. The distribution of the Dayak tribe in the Parindu District as shown in the following map:

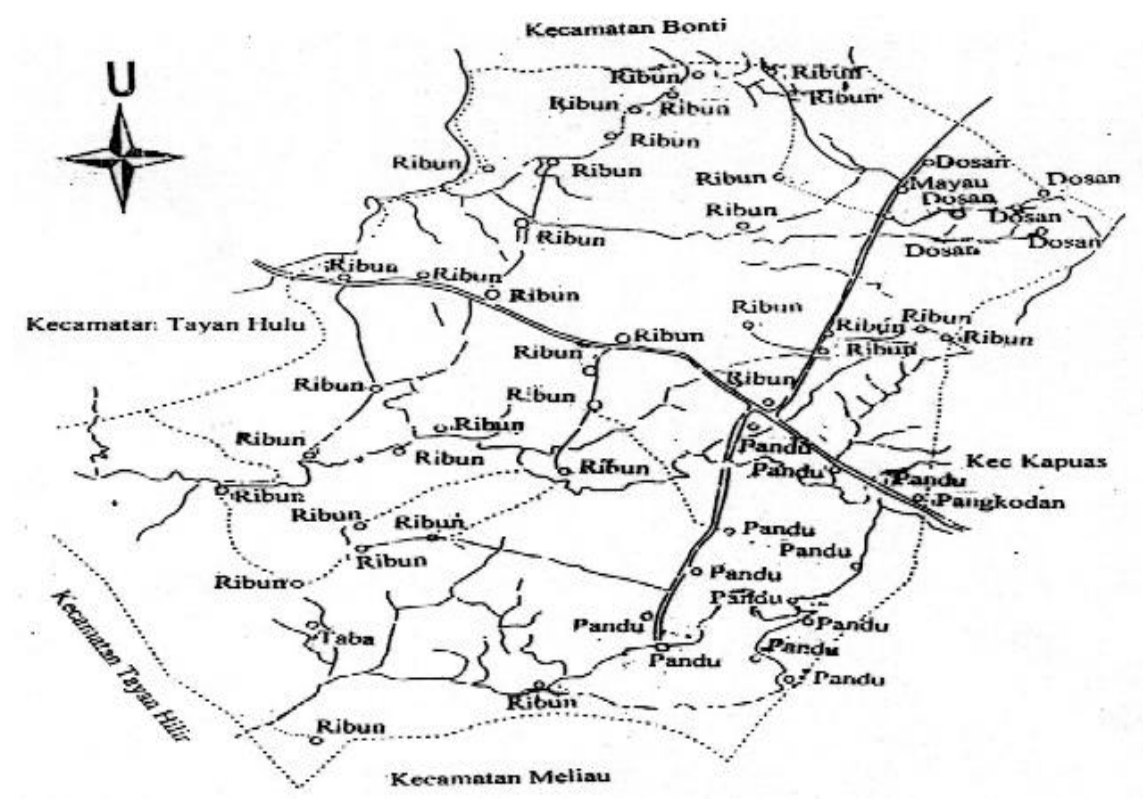

Figure 2. Map of the distribution of the Dayak Ribun

Source: Arkanudin, 2005

When compared to other Dayak sub-ethnics in Parindu District, the Ribun Dayak community socially, economically and culturally are among those who have the most contact with other ethnic groups or outsiders (from field observations). This is because the Dayak Ribun people inhabit an area where most of the villages are crossed by provincial roads that connect the capital of West Kalimantan Province (Pontianak) with other Regency cities such as 
Mempawah, Sanggau, Landak, Sekadau, Sintang, Melawi, and Kapuas Hulu, and are passed by the road leading to Sarawak Malaysia.

\section{Ribun Dayak Community Knowledge System}

The system of knowledge about natural phenomena related to farming plants which is marked at night the air will feel cold until the morning is a sign that people have arrived at the time to start clearing fields. If the star is seven in the East, while the one star is lower than the seven stars signifies that people are allowed to start planting rice.

Then, if in the sky, there are lines like walls and clouds resembling fish scales, it is a sign that the dry season will come. On the other hand, if the sky is red in the morning and the clouds clump together like mountains, it is a sign that the rainy day or season is coming. Symptoms of the arrival of the rainy season can also be known when the roots of wood that grow on the banks of the rivers sprout and many fruit trees flower.

Knowledge of the physical environment Dayak Ribun people have extensive knowledge of various types of forests as places for farming, they distinguish forests into 5 types, namely:

1. "Rimba " (primary forest) is a forest that has tall and large trees, while at the bottom of the tree there are thin shrubs.

2. "Dodak" (secondary forest) is a forest that is overgrown with tall, young and small trees, but at the bottom of the tree there are thick shrubs.

3. "Domun" (young secondary forest) is a forest that is overgrown with young and small trees and the bottom of the tree is thick undergrowth.

4. "Jamih" (groves) is a thicket forest that grows quite thick and there are several young wood trees that are still small.

5. " Lalang " ( field of reeds) is an expanse of land that was previously abandoned. Usually they let meadow Reed in a relatively long period (6-10 years) will be " Jamih " back. Scattered small trees began to appear to grow.

Among the five types of forest, according to them the best for farming are Rimba and Dodak. To ensure soil fertility, they usually examine the condition of the growing trees and the soil on the surface. If there are large and tall wood trees, it means that the land has not been cultivated for a long time and therefore the humus is very fertile.

The Ribun Dayak people also know the types of plants that make colors on woven mats or craft items. The red color can be obtained from the skin of the joronang fruit to give a red 
color to rattan and so on. Bark porete can give black and bark ngkubogng can be used as a glue on the wood. These types of plants are widely found around their villages or villages and are not cultivated, but grow wild in the forests.

The Dayak Ribun people also know the sap of wood called ipuh which contains poison and is very dangerous because it can be deadly. The sap of the ipuh wood is used to polish the tip of the spear or the tip of the chopsticks. Hunted animals such as deer, wild boars that are hit by the tip of a spear that has been given ipuh wood sap, even if only slightly injured, the animal will soon die Skin and flesh around the wound should be removed before cooking and should not be eaten.

The Dayak Ribun people also know the sap of wood called ipuh which contains poison and is very dangerous because it can be deadly. The sap of the ipuh wood is used to polish the tip of the spear or the tip of the chopsticks. Hunted animals such as deer, wild boars that are hit with the tip of a spear that has been given ipuh wood sap, even if only slightly injured, the animal will soon die Skin and flesh around the wound should be removed before cooking and should not be eaten.

\section{The Livelihood System of the Thousand Dayak People}

The life of the Ribun Dayak people depends on cultivation, which is done by shifting system. The main products are rice and a small amount of secondary crops which are consumed entirely by themselves. The area of fields cultivated in one family ranges from 2-4 hectares, they divide the fields into two types, namely dry land and swamp/swamp land (lobok), the type of rice planted is also different while the way of processing is the same, because the marsh/swamp land is in a field area of dry land.

In fields on land that are categorized as dry land, the rice varieties planted are local rice which is 6 months old. This type of rice such as feather rice (doman, kuik), red rice (sekapar), queen, entabai, bongkol, and several types of glutinous rice or pulut. While the fields in marsh or paya (lobok ) types of rice planted are labok rice, which is 6 months old, and Banjar kuning rice is 7 months old.

Each hectare of field requires 15-20 kilograms of rice seeds, the yields of which can reach approximately 1.5 tons of grain, 2-3 kilograms of corn seeds that yield $0.4-0.6$ tons of granulated corn, and cassava or cassava seeds. Between 500-700 trees, which yield between 1.5-2 tons. Rice from farming, they rarely sell it, as well as corn and cassava, apart from being used for their own consumption as well as for feeding pigs and chickens. 
Besides farming, they also cultivate rubber on the lands of former fields, especially those that are close to their settlements. This is intended to make it easier to take the results and maintain them. The condition of rubber plantations that grow not maintained provides a view that is difficult to distinguish from secondary forest because it is mixed with wild plants. Planting rubber trees on ex-field lands seems to be a form of protection or an effort to prove that they are recognized as customary property rights. According to Mudiyono (1995), this culture emerged allegedly since it was realized that rubber plants have a very significant economic value and on the other hand, the number of gardeners is increasing. With the emergence of smallholder rubber plantations, they themselves have begun to narrow their cultivation area. Each family Dayak Ribun, average a rubber plantation between 0,5 -2 hectares of trees between 300-1200 rod.

\section{Pama Panompo: The Ribun Dayak Belief System}

The Dayak Ribun community initially believed in supernatural things, both in ancestral spirits and rocks, mountains and so on, which were considered to have power and power in the region. At this time they have embraced religions that have been officially recognized by the government such as Catholicism and Protestantism.

Based on observations, even though they have embraced Catholicism and Protestantism, the customs and customary laws of the local community still apply as social control, only their implementation is adjusted to the religious teachings adopted and the development of the community itself. Sapardi (1991) suggests that local people (Dayak Ribun) believe in the existence of gods. The supreme male deity is called Abae Panompo (abae means grandfather), and his wife is called Nik Datuk (nik means grandmother).

Abae Panompo and Nik Datuk are assisted by Ambang Kawan, who functions as an intermediary between the gods (God) and humans. Underneath it, there are still good gods such as the God of Sambang Kuning, the God of Speech, the God of Plans, and the God of Sembawang Kuning Mayang Unraveling. These four gods are usually called a shaman (pamang) when treating sick people or rejecting bad dreams of people. In addition, there are still gods called Kamang-Kamang as the people of the gods.

According to the belief of the Ribun, that people are very sick because their soul (minu) is taken by demons, devils or ghosts (mut). To seize the soul of the sick from the evil spirit is done by the shaman by asking the gods for help. Usually the evil spirit wants to release the 
soul of the sick person on the condition that he asks for a ransom in the form of pigs, chickens, money, palm wine and others. The ransom is delivered by the gods to the shaman, and the shaman then tells the sick person's family that the request is fulfilled as soon as possible to save the sick person.

The Dayak Ribun people also believe in supernatural or magical powers. According to Koentjaraningrat (1992) supernatural powers can be in the form of community figures, certain human or animal body parts, large trees, natural phenomena, heirlooms, extraordinary or sudden events, and deviating from existing habits. In community life.

In the Ribun Dayak people, objects that are considered to have supernatural powers are unlimited, they can be in the form of plants (kiwara trees, ketapang), in the form of animals (birds, frogs), in the form of heirlooms or inanimate objects (sabers, stones). The excessive strength contained in these objects causes someone who has them to be careful in using them, because these objects in addition to bringing success, happiness and safety can also bring disaster, danger and death. The magical power can pass from one medium to another, for example from animals into the human body or vice versa.

The Ribun Dayak people, in addition to believing in supernatural powers, also believe in spirits. According to them, in this world apart from having a single power called panompo (God), there are also other rulers in the form of ancestral spirits called Pama. Pama are holy spirits who always protect and nurture, guard and care for their surviving descendants at the will of panompo, while mun are evil spirits who like to disturb humans both physically and spiritually. This evil spirit is the incarnation of the spirits of the dead who during their life had bad habits and behavior. If there is a disaster or disease outbreak and other things, then they assume the ghosts are angry.

So strong is their belief in ghosts $(m u t)$. So when starting a job, the Ribun Dayak people always perform certain ceremonies. This is so that the work to be carried out can be completed without a hitch. This ceremony also means that they still strongly believe that in their forest not only live big trees, but also live spiritually. According to their beliefs, based on the place, the ceremonies that are always performed by the Ribun Dayak people can be divided into three types, namely:

1) The ceremony is carried out in the household environment, usually carried out in the kitchen, front, house or front porch, in the corners of the house, rice barn and so on. The ceremonies include: (1) Nsangi Matathn Punu Dik Buhok, which is a ceremony 
performed because of a bad dream, so that the dream does not really happen; (2) Nsangi Gawe, which is a ceremony carried out because of getting a lot of fortune, such as a successful rice harvest, cattle growing well; (3) Nsangi Reply Intention, namely a ceremony carried out because the request is granted; (4) Human life cycle ceremonies such as the Nsangi botanek ceremony, namely the ceremony of bathing a 4-day-old baby; Nsangi Bobibo, the wedding ceremony; Nsangi Nyopi, the death ceremony.

2) The ceremony carried out in the village such as a ceremony to summon the spirit of rice, which is commonly called the rice party or Nusu Minu Podi, this ceremony is intended to summon the spirit of rice to be stored in the barn (juhuong). The ceremonial feast of storing rice in the barn (juhuong) is called nsangi juhuong or semayong juhuong. The Kanayant Dayak in Pontianak and Hedgehog are called Naik Dango. The implementation of the nsangi juhuong ceremony usually falls in May every year, which is carried out in turns in the village or village of the Ribun Dayak people.

3) The ceremonies performed on the farm/forest called mmuh is ceremony Nsangi mmuh, the ceremony performed at the time of going to open fields and to nsangi mmuh done on time will reap rice paddy fields usually when old.

\section{Conclusion}

Based on the result of the research that has been describe, it can be concluded that this finding is that the Dayak Ribun community's knowledge system about community, source of livelihood/livelihood, and belief/religion has a unique treasure that forms a complete and complex local knowledge system. This knowledge system, then became important in the life of the Dayak Ribun community, because it was an ancestral heritage which they hold firmly to this day as a guide in their daily life.

The implication of the conclusions that can be suggested by the author is that the local knowledge system of the Dayak Ribun community needs to be preserved and recognized by the state. With the development and advancement of technology today, it is not impossible that the local knowledge inherited from our ancestors can disappear and be eroded by the times. Then, for the sake of recognizing the Dayak Ribun indigenous people in Sanggau Regency, West Kalimantan, it is necessary to have a serious socialization and implementation 
of the Sanggau Regency Regional Regulation Number 1 of 2017 concerning Recognition and Protection of Indigenous Law Communities.

\section{References}

[1] Arkanudin. (2011). Sebuah Penelitian Antropologi Perubahan Sosial Masyarakat Peladang Berpindah. Pontianak: STAIN Press.

[2] Arkanudin, Rupita., \& Zahriadi. (2007). Resolusi Konflik Pertanahan Berdasarkan Pranata Adat: Studi Pada Etnik Dayak Ribun yang Berada di Sekitar PIR-Bun Kelapa Sawit Parindu, Sanggau, Kalimantan Barat. Pontianak: Fakultas Ilmu Sosial dan Ilmu Politik Universitas Tanjungpura.

[3] Asfar, D. aA. (2004). Sastra Lisan Iban Sungai Rimbas Sarawak: Perspektif Etnopuitika. Tesis Universiti Kebangsaan Malaysia.

[4] Asfar, D. A. (2017). Diftongisasi dalam Bahasa Ribun. Tuah Talino: Jurnal Bahasa dan Sastra. 11(1): Doi: https://doi.org/10.26499/tt.v11i1.1046

[5] Crevello, S. M. (2003). Local Land Use on Borneo: Applications of Indigenous Knowledge System and Natural Resource Utilization Anong the Benuaq Dayak of Kalimantan, Indonesia. Doctoral Dissertations: Louisiana State University and Agricultural and Mechanical College.

[6] Darmadi, H. (2016). Dayak Asal Usul dan Penyebarannya di Bumi Borneo. Sosial Horizon: Jurnal Pendidikan Sosial. 3(2):322-340.

[7] Istiyani, C. P. (2008). Peta Keberagaman Subsuku Dayak di Kalimantan Barat. Pontianak: Institut Dayakologi.

[8] Kim, S. H. (1993). Identifying alternative linkages among philosophy, theory and method in nursing science. Journal of Advanced Nursing. 18, 793-800.

[9] Koentjaraningrat. (1992). Manusia dan Kebudayaan di Indonesia. Jakarta: Djembatan.

[10] Koeswinarno. (2015). Memahami Etnografi ala Spradley. Jurnal SMaRT. 1(2):257-265.

[11] Mona. (2003). Onok Adak Onok Nusantara. Dalam Kumpulan Diskusi dan Presentasi KEDAI (Kelompok Diskusi Adat Indonesia). Jakarta: International Centre for Research in Agroforestry.

[12] Mudiyono. (1995). Perubahan Sosial dan Ekologi Peladang Berpindah, Pontianak: Dalam Suara Almamater Universitas Tanjungpura, No II Tahun V Nopember 1990. 
[13] Mulyoutami, E., Rismawan, R., \& Joshi, L. (2009). Local knowledge and management of simpukng (forest gardens) among the Dayak people in East Kalimantan, Indonesia. Forest Ecology and Management. 257, 2054-2061. Doi:10.1016/j.foreco.2009.01.042

[14] Niko, N. (2016). Perempuan Dayak Benawan: Kedudukan Pada Struktur Domestik \& Publik. Yogyakarta: Deepublish.

[15] Niko, N. (2020). Gender Struggle: What Can We Learn from the Dayak Benawan Women?. Walailak Journal of Social Science. 13(2):269-292. Retrieved from https://so06.tci-thaijo.org/index.php/wjss/article/view/234156

[16] Perda Kabupaten Sanggau Nomor 1 Tahun 2017 Tentang Pengakuan dan Perlindungan Masyarakat Hukum Adat. Retrieved from: https://peraturan.bpk.go.id/Home/Details/54925/perda-kab-sanggau-no-1-tahun-2017

[17] Sapardi. (1991). Pengaruh Perkebunan Inti Rakyat Terhadap Rumah Tangga Petani di Kecamatan Parindu, Tesis, Program Pascasarjana Universitas Indonesia.

[18] Spradley, James. P. 1980. Participant Observation. United State of America: Holt, Ronehart and Winston.

[19] Sunker, A., Saraswati, A., \& Santosa, Y. (2019). Indigenous Dayak People's Perceptions of Wildlife Loss and Gain Related to Oil Palm Development. International Journal of Environmental and Ecological Engineering. 13(2):37-42. Doi: doi.org/10.5281/zenodo.2571883

[20] Suwarno. (2017). Budaya Huma Betang Masyarakat Dayak Kalimantan Tengah dalam Globalisasi: Telaah Konstruksi Sosial. Lingua. 14(1):89-102.

[21] White, B. (2009). Dibalik pertarungan sumber daya alam Indonesia: ekologi politik dan penerapannya pada studi dan perjuangan lingkungan hidup. Tanah Air. Edisi: OktoberDesember, 3-9. 